\section{Mountain glaciers of NE Asia in the near future: a projection based on climate-glacier systems' interaction}

Mountain glaciers of NE Asia

\section{D. Ananicheva et al.}

Title Page

Abstract

Introduction

Conclusions

References

Tables

Figures

14

$\rightarrow$

M. D. Ananicheva ${ }^{1}$, A. N. Krenke ${ }^{1}$, and E. Hanna ${ }^{2}$

${ }^{1}$ Institute of Geography, Russian Academy of Sciences, Moscow, Russia

${ }^{2}$ Department of Geography, University of Sheffield, UK

Received: 22 November 2007 - Accepted: 26 November 2007 - Published: 7 January 2008

Correspondence to: E. Hanna (ehanna@sheffield.ac.uk)

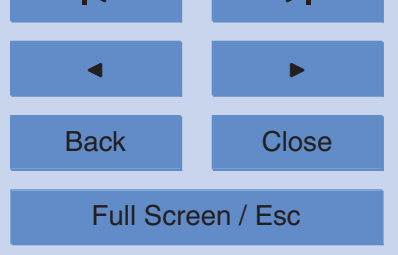

Printer-friendly Version

Interactive Discussion 


\section{Abstract}

In this study we consider contrasting continental (Orulgan, Suntar-Khayata and Chersky ranges located in the Pole of Cold area at the contact of Atlantic and Pacific influences) and maritime (Kamchatka under the Pacific influence) Russian glacier sys-

5 tems. Our purpose is to present a simple method for the projection of change of the main parameters of these glacier systems with climate change. To achieve this aim, we constructed vertical profiles of mass balance (accumulation and ablation) based both on meteorological observations for the mid to late 20th century and an ECHAM4 GCM scenario for 2040-2069. The observations and scenario were used for defining the recent and future equilibrium line altitude (ELA) for each glacier system. The altitudinal distributions of the areas covered with glacier ice were determined for present and future states of the glacier systems, taking into account the correlation of the change of the ELA and glacier-termini levels. We also give estimates of the possible changes of the areas and morphological structure of North-eastern Asia glacier systems and their 15 mass balance characteristics from the ECHAM4 scenario. Finally, we compare characteristics of the continental and maritime glacier systems stability under conditions of global warming.

\section{Introduction}

The projection of glacier change, not only for individual glaciers but also for groups of them (glacier systems), is a very important goal of global environmental change studies (e.g. Dowdeswell and Hagen 2004). The term "glacier system" is considered as a set of glaciers united by the joint links with the environment: the same mountain system or archipelago and similar atmospheric circulation patterns; the glaciers are related to each other usually by parallel links from atmospheric inputs and topographical forms to hydrological and topographical outputs, and demonstrate common spatial regularities of the regime and other features. In this paper we present a simple method for prog-

Mountain glaciers of NE Asia

M. D. Ananicheva et al.

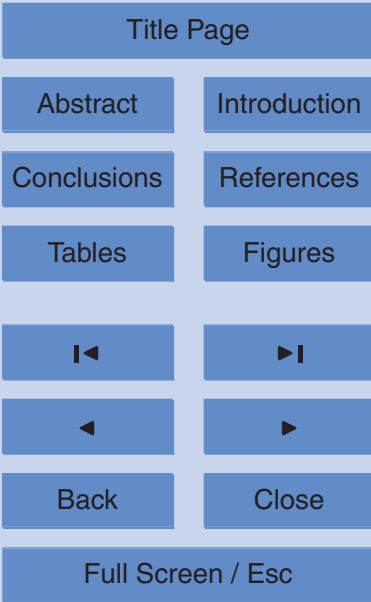

Printer-friendly Version

Interactive Discussion 
nosis of change in glacier systems' parameters and the application of this method for the region of Northeast Asia.

From the glacier systems of NE Asia we have chosen to study the continental glacier systems of North-eastern Siberia - Orulgan (a part of Verkhonyansk Range in Fig. 1), 5 Suntar-Khayata and Chersky ranges - and the marine glacier systems of Kamchatka - Sredinniy, Kronotsky ranges, Kluchevskaya, Tolbechek, Chiveluch volcano groups, etc (Fig. 1, Table 1). Observations of both these glacier regimes are available only for one or two benchmark glaciers, so we used the data from The USSR Glacier Inventory $(1965-1982)^{1}$, which was based on remote sensing data of these regions' glaciers 10 (Orulgan Range - 1958, 1963; Suntar-Khayata Mountains - 1945, 1959, and 1970; Chersky Range - 1970s, Kamchatka - 1950). NE Siberia has undergone both winter and, to a lesser extent, summer warming since around 1960 until present, as well as the intensification of cyclonicity and precipitation (Ananicheva et al., 2003; IPCC, 1995). Due to these climatic tendencies the proportion of solid precipitation here is increasing 15 (Ananicheva and Krenke, 2005). Significant warming is also observed in Kamchatka (Shmakin and Popova, 2006).

\section{Glaciers studied}

\subsection{The Suntar-Khayata range}

The Suntar-Khayata Range serves a watershed between the river basins of Aldan and the Indigirka tributaries entering the Arctic Ocean. Its elevations reach almost $3000 \mathrm{~m}$. It is one of the largest knots of present glaciations in NE Russia - about 195 glaciers cover $163 \mathrm{~km}^{2}$ (Ananicheva et al., 2006). The main source of the glacier systems'

\footnotetext{
${ }^{1}$ We used the following parts of the USSR Glacier Inventory: vol. 17 (Lena-Indigirka basins region), issue. 2, part 2 (Orulgan), 1972, 43 pp.; issue 3, part 1, issue 5, part 2, issue 7, parts 2 and 3, 1981, 88 pp.; vol. 19 (North-East), part 3, 1981; vol. 20 (Kamchatka), parts 2-4, 1969, $74 \mathrm{pp}$.
}

\section{2, 1-21, 2008}

Mountain glaciers of NE Asia

M. D. Ananicheva et al.

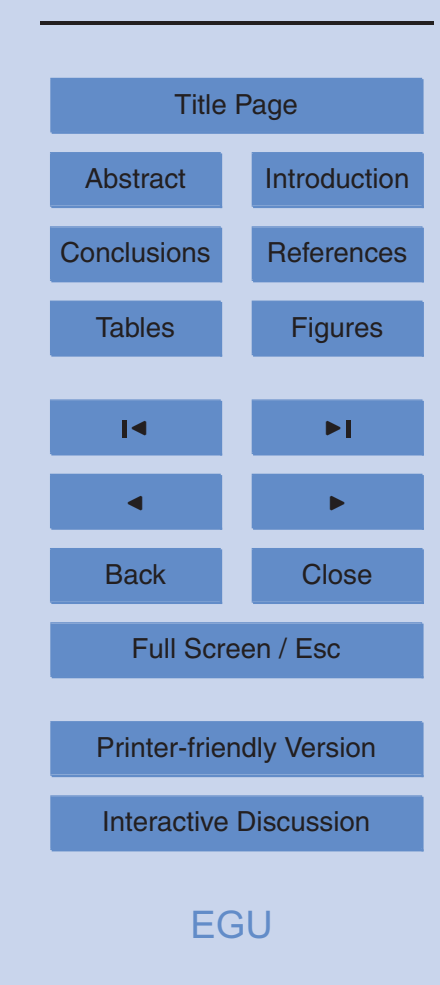


nourishment is moisture that has been brought from the Pacific and the Okhotsk Sea in particular in spring, summer and early autumn. For the Northern glacier massive of the range, Arctic air invasions are also significant in winter.

\subsection{The Chersky Range Mountain system}

5 The Chersky Range Mountain system (which contains a number of ridges) occupies the inner part of NE Siberia located to the north of the Suntar-Khayata Range and closer to the Aleutian Low, in the area of prevailing moisture nourishment from the Pacific Ocean. Therefore the basic equilibrium line altitude (ELA) here is lower: 2150-2180 m against 2350-2400 m in Suntar-Khayata Range. According to the latest assessments the Chersky Range contains about 300 glaciers which cover $113 \mathrm{~km}^{2}$ (Ananicheva at al., 2006).

\subsection{Orulgan Ridge}

The glaciers of Orulgan Ridge (Verkoyansky Range) were first mapped in the 1940s. The present glaciation is located along the main watershed line, mainly on leeward

(eastward-facing) slopes in concave relief forms - in two sites stretching $112 \mathrm{~km}$ and $25 \mathrm{~km}$ north to south. Glaciers of Orulgan (basically corrie and hanging by morphology; about 80 glaciers covering $20 \mathrm{~km}^{2}$ ) exist on account of climate since the topography is relatively low. The modern glaciation is the only one in continental Russia where glacier termini descend to $1500 \mathrm{~m}$; the ELA is lower than $2000 \mathrm{~m}$, and the glaciers face incoming cyclones from the Atlantic and western sector of Arctic.

\subsection{Kamchatka glaciation}

The Kamchatka glaciation consists of 448 glaciers, with a combined area of about $906 \mathrm{~km}^{2}$. Of these glaciers, $38 \%$ are located in the regions of active volcanism, $44 \%$ on ancient volcanic massifs (regions of Quaternary volcanism), and less than $19 \%$ in

Mountain glaciers of NE Asia

M. D. Ananicheva et al.

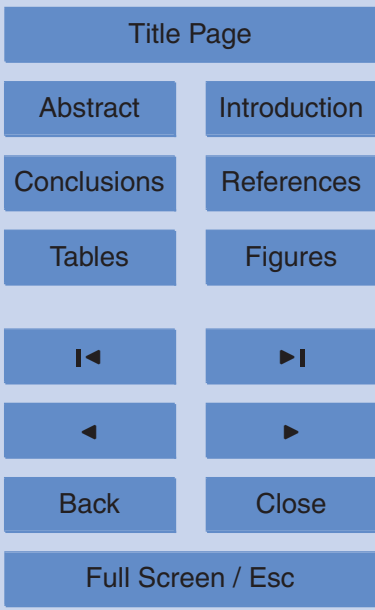

Printer-friendly Version

Interactive Discussion 
non-volcanic regions. Notably, out of all the glaciated regions considered in this study, volcanism is the characteristic feature only for Kamchatka glaciers.

The Kamchatka Glaciation lies between 50 and $60^{\circ} \mathrm{N}$, near the Pacific Ocean and the Sea of Ohkotsk, which feed the glaciers with moisture from cyclones related mainly to 5 the Aleutian Low. Within the Kamchatka Peninsula precipitation is higher than over any other region of Russia and shows seasonal variations being under the influence of the monsoon (Muraviev, 1999). Precipitation increases from north-west $\left(400 \mathrm{~mm}\right.$ year $^{-1}$ ) to south-east (up to $2000 \mathrm{~mm} \mathrm{yr}^{-1}$ ) according to lowland weather stations (Russian Hydrometeorological Service, http://www. meteo.ru). The temperature and precipitation 10 regimes, other climatic factors, relief and geological structures have led to the modern marine-type glaciation. Due to abundant precipitation on Kronotsky Peninsula, which faces the Pacific Ocean coast, the glaciers there descend down to 250-500 $\mathrm{m}$ a.s.I.

\section{Method/data}

Our method for defining the morphology and regime of glacier systems is based on 15 average changes of the mean ELA (which are defined by the ratio of accumulation and ablation mass-balance profiles) under climate-change scenarios. The method is consistent with both GCM and palaeo-analogue scenarios. We chose the ECHAM4 /OPYC3 - GGa11, scenario, which predicts one of the greatest warmings by 2100 in comparison with other GCMs: thus we evaluate the maximum likely reduction of the glaciation. The model is a spectral transform model with 19 atmospheric layers, and the results used here derive from experiments performed with spatial resolution T42, which corresponds to about $2.8^{\circ}$ longitude/latitude resolution (Bacher et al., 1998). The choice is conditioned by the purpose to understand how much the glacier systems of the NE Asia, which are now under warming, change if regional climate change either persists at the current rate or is somewhat enhanced.

We considered 17 glacier systems from the two different climate and relief regions of Russian Asia - NE Siberia (7), and the Kamchatka Peninsula (10).Using climatic data

Mountain glaciers of NE Asia

M. D. Ananicheva et al.

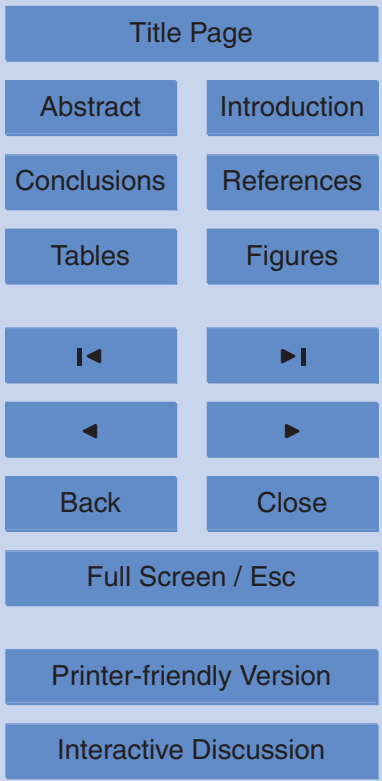


from the second half of the 20th century (Russian Hydromet Service archives, http: //www.meteo.ru) and climatic scenarios the mean vertical mass-balance (accumulation and ablation) profiles for these regions were constructed. These profiles became the basis for our projection of glacier evolution. The cross-sections of the vertical mass5 balance profiles (i.e. where the accumulation and ablation profiles intersect) give the values of the present-day and projected future ELA.

By using the USSR Glacier Inventory for each system we constructed hypsographic schemes showing the distribution of glaciated area versus altitude (Fig. 2: examples of hypsographic curves for NE Siberia). The ELA was assumed, when unknown, to 10 be the arithmetic mean of the highest and lowest point of a glacier in the system. This assumption, based on the Gefer/Kurowski method (e.g. Hess, 1904; Kalesnik, 1963), is used where glaciers are in balance with climate, which can reasonably be assumed to be the case for the USSR Glacier-Inventory data (1950s to 1970s). The area share of elevation intervals occupied with ice, is assumed at this stage of the work to linearly decrease with altitude while a glacier is retreating. These elements constitute the essence of our new approach for assessing glacier-system change due to climatic fluctuations.

\subsection{Precipitation/temperature data}

Glacier systems analysed in this paper, represent a wide spectrum of morphology 20 and regime types - from small corrie glaciers of the Orulgan range to large dendritic glaciers of the Chersky Range and specific volcano-glacier complexes of Kamchatka. The glacier nourishment conditions also vary widely - from plentiful (monsoon type) in the eastern parts of Kamchatka (glaciers of the Kronotsky range) to insufficient on the south-east of Orulgan. The Chersky and Suntar-Khayata ranges hold an intermediate position in terms of glacier accumulation-ablation rate. Correspondingly we may expect different reactions of these glacier systems to climate warming.

According to our chosen scenario the mean summer temperature would increase by between $3.1^{\circ}$ and $4.0^{\circ} \mathrm{N}$ throughout the study region by 2040-2069, greatly exceed-

Mountain glaciers of NE Asia

M. D. Ananicheva et al.

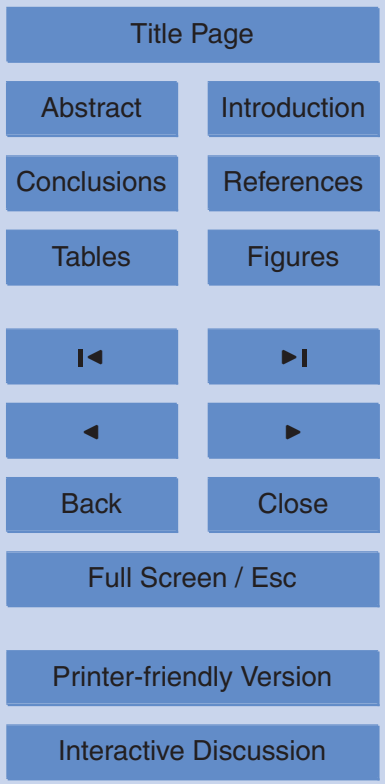


ing the temperature difference between 30-year periods before and after the start of warming around 1960 (Ananicheva et al., 2002). The daily total precipitation, given by this GCM, was recalculated to solid precipitation (for the accumulation on glaciers) in monthly amounts, using the Bogdanova method (Bogdanova, 1976; Bogdanova et 5 al., 2002), which calculates the solid-precipitation fraction according to mean monthly temperature and elevation, and taking account of the model baseline and increased (projected) temperatures. In north-east Siberia under the scenario of intense warming, solid precipitation would tend to grow everywhere except the Southern Massive of Suntar-Khayata. The situation on Kamchatka is the opposite: solid precipitation would decline except in the south-east, where it might increase slightly.

To calculate the vertical distribution of present mass-balance components we used all available climatic data, which mainly cover the second half of the Twentieth Century. This timeframe corresponds to the baseline (1959-1990) period used for reference in the ECHAM4 scenario of climate change for the next 80 years. Our baseline period 15 approximately corresponds to the state of the glaciation reflected in the USSR Glacier Inventory and partly covers the time preceding its compilation.

To complement rare meteorological-station data for high elevations (above $1000 \mathrm{~m}$ ), we used accumulation at the mean ELA for whole glacier systems, which was calculated from the Glacier Inventory data or obtained from their maps (Krenke, 1982; 20 Ananicheva and Krenke, 2005). Among glacier regime characteristics related to high altitudes, ablation is considered more reliable than accumulation because it is relatively easy to calculate based on air temperature, since temperature lapse rates are easier to define and therefore better known than precipitation lapse rates (e.g. Hanna and Valdes, 2001). Accumulation is then set equal to equal to ablation of the mean ELA.

25 For each glacier system mentioned above, vertical profiles of ablation $(A)$ and accumulation $(\mathrm{C})$ were constructed using the following methods:

\section{Mountain glaciers of} NE Asia

M. D. Ananicheva et al.

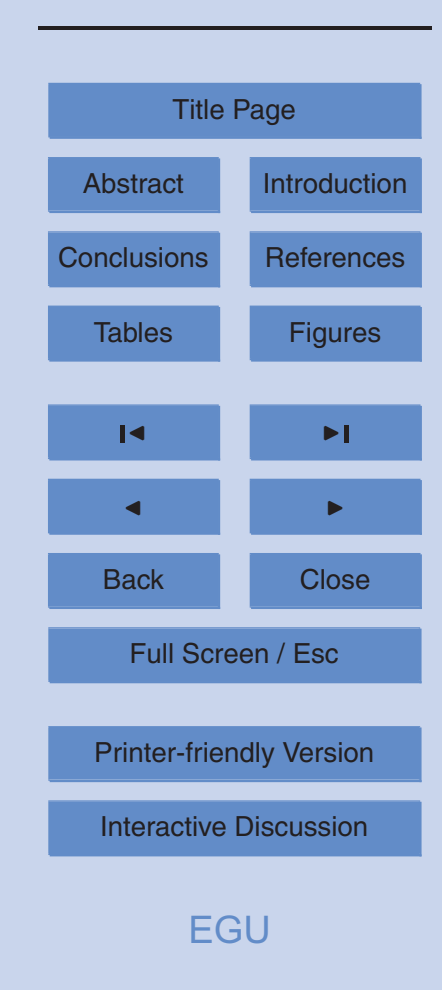


Accumulation was calculated based on solid precipitation measurements from meteorological stations; Ablation by the relationship of ablation and mean summer air temperature. For NE Siberia precipitation and temperature data were available only up to 5 the height of $1400 \mathrm{~m}$ except for the high altitude (2068 $\mathrm{m}$ a.s.l.) meteorological station "Suntar-Khayata", which operated for 9 years (1957-1966) at the terminus of Glacier 31 in the Northern Massive of Suntar-Khayata Range. Based on this station's data and data from an intermediate station at Nizhnya Baza $(1350 \mathrm{~m})$, located in the western slope of Suntar-Khayata Range, temperature gradients of $0.68^{\circ} / 100 \mathrm{~m}$ below $1000 \mathrm{~m}$, $0.50^{\circ} / 100 \mathrm{~m}$ between $1000-1500 \mathrm{~m}$ and $0.60^{\circ} / 100 \mathrm{~m}$ above $1500 \mathrm{~m}$ were used for summer.

Weather stations on Kamchatka are situated within the altitude range of 100$400 \mathrm{~m}$ a.s.I. In situ meteorological observations in Avachinskaya Volcano group (19631974 and 1975-1979) were conducted to a height of $1500 \mathrm{~m}$. The temperature gradient everywhere increases with altitude. However, inversions are not characteristic for this region, in contrast to North-east Siberia (Matsumoto et al. 1999). Based on these observations, we adopted lapse rates of $-0.35^{\circ} \mathrm{C} / 100 \mathrm{~m}$ between 100 and $1000 \mathrm{~m}$, $-0.55^{\circ} \mathrm{C} / 100 \mathrm{~m}$ between 1000 and $2000 \mathrm{~m}$, and $-0.60^{\circ} \mathrm{C} / 100 \mathrm{~m}$ above $2000 \mathrm{~m}$ (Vinogradov, 1975; Vinogradov and Martiaynov, 1980)

20 We extrapolated precipitation in NE Siberia according to the Suntar-Khayata meteorological station and in Kamchatka by pluvial gradients identified by observation at $1500 \mathrm{~m}$, incorporating corrections based on accumulation $(\mathrm{C})$ values at the ELA - with $C$ defined based on its equity to ablation $(A)$ at this level. The next step was to construct a corresponding vertical profile of ablation for present-day climate (the baseline 25 period). In NE Siberia where glaciers are cold-based, the superimposed nourishment prevails; therefore a significant fraction of meltwater refreezes and then melts again at the surface. In this case it is possible to use a regional variant of the global formula relating ablation to summer temperature, presented by Krenke and Khodakov 1966 In

\section{Mountain glaciers of} NE Asia

M. D. Ananicheva et al.

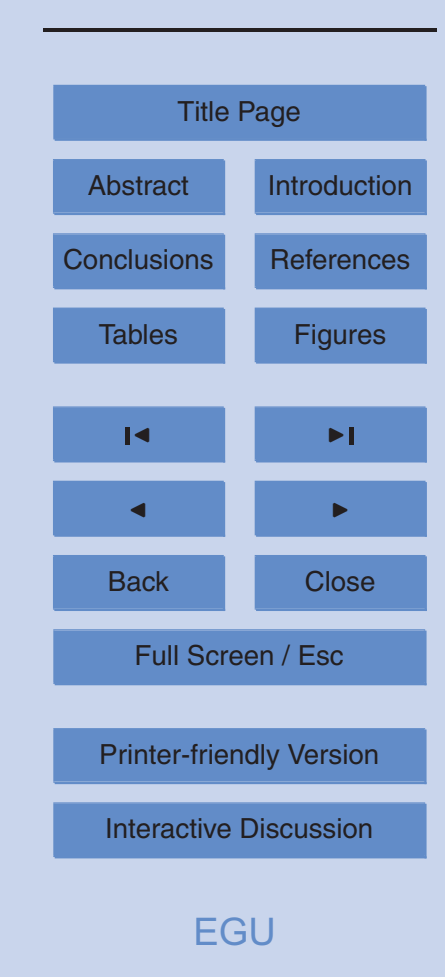


Krenke, 1982), which was proposed by Koreisha (1991) and confirmed in calculations for Glacier 31 for reconstruction of the Suntar-Khayata glaciation during the Holocene optimum (Ananicheva and Davidovich, 2002):

$A=\left(T_{\text {sum }}+7\right)^{3}$

5 where $A$ is ablation in $\mathrm{mm}$, and $T_{\text {sum }}$ is the mean summer air temperature over the glacier surface for June, July, and August.

In Kamchatka, in marine climate conditions we used a slightly modified variant of the formula (Krenke, 1982):

$A=1.33\left(T_{\text {sum }}+9.66\right)^{2.83}$

10 In both cases $T_{\text {sum }}$ over the glacier surface $\left(T_{g}\right)$ was obtained according to:

$T_{g}=0.85 T_{n g}-1.2$,

where $T_{n g}$ is the temperature over the rocky surrounding surface, as described in Davidovich and Ananicheva (1996).

The calculation of accumulation profiles consists of transformation with the help of a coefficient of concentration $\left(K_{c}\right)$. The solid precipitation share for each month, and then annually was defined, as explained above, by the Bogdanova method (Bogdanova, 1976; Bogdanova et al., 2002). Then, to take account of the morphological type of a glacier in the glacier system, we introduced the concentration coefficient for snow drift, avalanche snow transfer on glaciers, and its drift from volcano slopes.

20 According to recommendations given by Krenke (1982), in the situation where corrie type glaciers prevail (such as in the Orulgan, Valagiskiy, Tumrok and Gemchen ranges) $K_{c}$ is assumed to be 1.6. For the Chersky, Suntar-Khayata, and Sredinny ranges, where medium-sized valley glaciers dominate, $K_{c}$ is assumed to be 1.4. For volcanoes covered by ice caps on the cones in combination with large valley glaciers, we used $K_{c}$ as suggested as 1.4 until the cone end, and then decreased $K_{c}$ from 1.0 to $0.6-0.7$ on the slopes, from which snow drift prevailed. 
For some glacier systems of Kamchatka we also used the mass-balance component profiles, obtained by Davidovich (2006) via the same approach. Examples of massbalance (accumulation and ablation) curves for both Northeast Siberia and Kamchatka are given in Fig. 3.

5 3.3 Method of glacier change projection

This section of the work involved the construction of projected ablation and accumulation curves, $C_{p}$ and $C_{p}$, for the climate of 2040-2069, based on $A$ and $N$ for the present time period. For ablation/accumulation we used the assumption that the temperature shift, presented in the scenario for each grid point within which the given glacier system 10 is located, spreads over the entire (real-surface) altitudinal range encompassed by that pixel. If the glacier system is covered by a number of grid points, we used the mean value of the temperature shift.

\subsection{Projected accumulation/ablation calculation}

For all glacier systems considered, the mean summer temperature increase from 15 current conditions is projected to lie within the $3.1^{\circ}-4.0^{\circ} \mathrm{N}$ range. These summertemperature increases were incorporated in the calculation of ablation described above. It should be noted that we used the temperature increase at the ice-rock boundary because - due to microclimatic influences and the melt process - glacier surfaces depress air temperature compared with non-glacier surfaces and so experience a reduced warming rate.

We used modelled daily precipitation to calculate monthly values of solid precipitation for both the baseline and projected time period using the Bogdanova $(1976,2002)$ method and the modeled (increased) temperatures. The purpose was to obtain ratio coefficients of solid precipitation for the projected compared with present periods for all 25 glacier systems. Note that in NE Siberia, under the significant warming of the given scenario, solid precipitation is predicted to increase everywhere (coefficients are from

Mountain glaciers of NE Asia

M. D. Ananicheva et al.

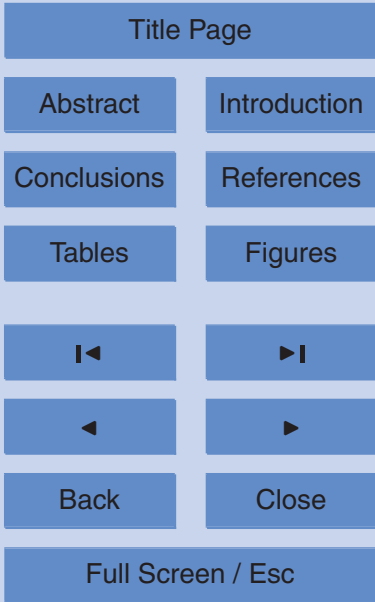

Printer-friendly Version

Interactive Discussion 
1.09 to 1.46) except for the Southern Massif of Suntar-Khayata (0.99). In Kamchatka the situation is the opposite: solid precipitation decreases slightly $(0.74-0.96)$ except for the South-east where it rises slightly (1.08). Thus the southern parts of the region under consideration will be so warm that the share of solid precipitation will decrease 5 due to the longer time period with positive temperatures.

For the use of these coefficients in the calculation of accumulation for the projected period, we assumed that this ratio did not change with altitude. As a result we obtained vertical curves of $N_{p}$ for all glacier systems in 2040-2069.

The cross-sections with the scenario-based curves $A_{p}$ are taken to obtain the mean 10 ELA for 2040-2069 for the glacier system - ELA ${ }_{p}$. Its shift is rarely higher than the highest point of the area of accumulation $\left(H_{\text {high }}\right)$ in the system (a scenario which would mean that the glaciation should disappear).

\subsection{The projection of the glacier termini shift}

In other cases it is assumed that after adaption of the glacier to the new climate in 15 accordance with the Gefer method of ELA identification (according to which the ELA is the arithmetic mean of the highest and the lowest glacier points; Kalesnik 1963), the elevation difference between the top of the glacier $H_{\text {high }}$ and $E L A_{p}$ is equal to the elevation difference between $\operatorname{ELA}_{p}$ and glacier terminus $\left(H_{\text {ends }}\right)$. Under the assumption that the same is valid for whole glacier systems, we derive the following formula for the 20 altitude of the lowest glacier height position:

$H_{\text {ends }}=\mathrm{ELA}_{p}-\left(H_{\text {high }}-\mathrm{ELA}_{p}\right)=2 \mathrm{ELA}_{p}-H_{\text {high }}$

Using this equation, we obtained projected distributions of ice against altitude for the glacier systems under consideration for the period 2040-2069. Their lowest point coincides with $H_{\text {ends }}$, where glaciated area equals zero, and the highest point remains unchanged. The ice distribution of intermediate steps in elevation changes in proportion to altitude from zero (at $H_{\text {high }}$ ) to unity (at $H_{\text {ends }}$ ) relative to the baseline period. This assumption was based on observed data: for example, Fig. 4 shows the proportional

\section{2, 1-21, 2008}

Mountain glaciers of NE Asia

M. D. Ananicheva et al.

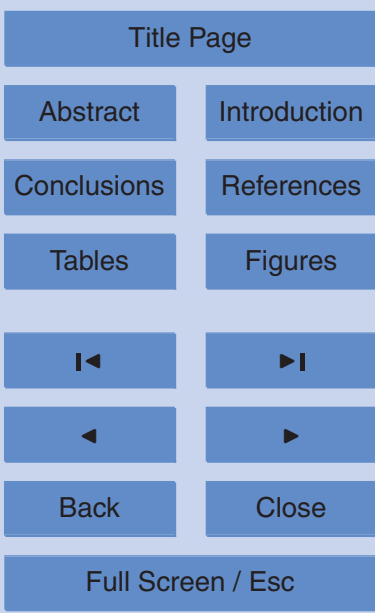

Printer-friendly Version

Interactive Discussion 
change of ice area by altitude for Glacier 31 (Northern Massif of Suntar-Khayata) for 1957 (the International Geophysical Year, when many such measurements began) and 2001.

Projected ice areas for the glacier systems were multiplied by $A_{p}$ and $C_{p}$ to derive the 5 distribution of projected ablation/accumulation versus altitude for the climatic conditions of the scenario (2040-2069). See Fig. 3, where projected balance profiles are indicated in broken line.

The comparison of the projected mass-balance components' profiles with the elevations of the "beginnings" and "ends" of glaciers with the USSR Inventory data (194010 1970) also enables an estimation of the change of the ratio of glacier morphology types and related parameters - not just glacier balance and area - under climate-change scenarios.

\section{Results and discussion}

As a result of the ECHAM4 scenario described above, we obtained the following pro15 jected assessments of the ELA change. The shift upward of the ELA altitude, $\Delta H_{\text {ela }}$, is less in northern parts of NE Siberia than in the south $(230 \mathrm{~m}$ as against $500 \mathrm{~m}$ in the south). In Kamchatka $\Delta H_{\text {ela }}$ as a rule is more significant and depends on precipitation rate. The largest $\Delta H_{\text {ela }}$ (up to $1210 \mathrm{~m}$ ) was found in the south of Ichinskiy Volcano, located in the "rain shadow" of the Sredinniy Range (Table 1).

20 The change in glaciated area is anticipated to range from a complete disappearance of some minor glacier systems, to the preservation of $70 \%$ of the present area (Kluchevskaya volcano group) and $50 \%$ of contemporary glaciated area (Shiveluch and Tolbachek volcanoes). Under the warming scenario as calculated by our approach, glaciers will not be present in southern systems of NE Siberia - southern knots of Orulgan glaciation and the Suntar-Khayata Mountains, on the Sredinniy Range of Kamchatka and around Ichinskiy Volcano. Those glaciers covering the volcanoes of SE Kamchatka and receiving intensive nourishment due to the elevation of the peaks and

\section{Mountain glaciers of} NE Asia

M. D. Ananicheva et al.

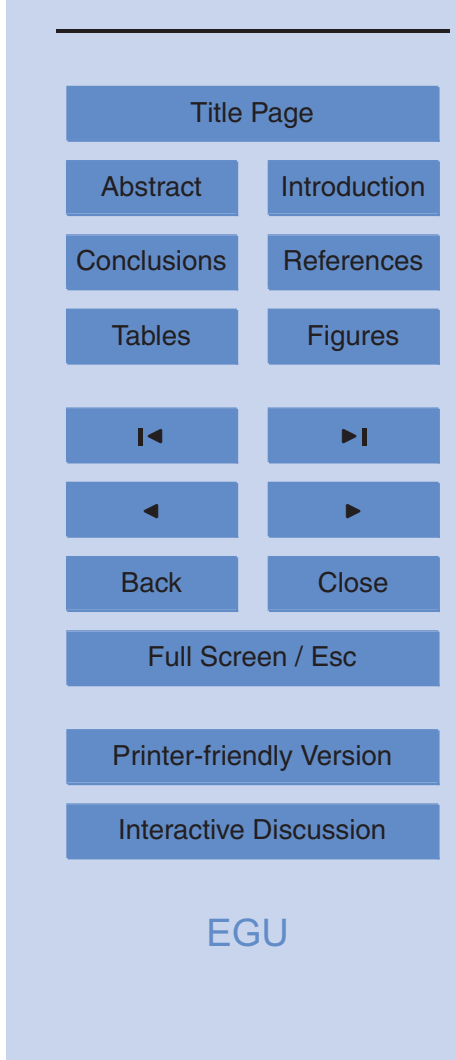


proximity of the Pacific Ocean would preserve more than $40 \%$ of their area.

As for the intensity of mass exchange at the ELA, we can expect the following changes in ablation and accumulation during the projected period compared with the baseline period. $\triangle \mathrm{A}, \mathrm{C}$ at the ELA is greater for NE Siberia on the north of the Orul5 gan, Chersky, and Suntar-Khayata ridges, where precipitation due to warming will grow (Orulgan derives moisture from the Atlantic; the Chersky, while Suntar-Khayata ridges also receive moisture from the Pacific Ocean) - from 200 to almost $500 \mathrm{~mm}$ (accumulation=ablation at the ELA). In glacier systems of Kamchatka only the Kronotsky Range and volcanoes of the South-east part of the peninsula are characterized by high $\triangle A, C$ 10 at the ELA - from 200 to $450 \mathrm{~mm}$ (these are areas of plentiful precipitation, and despite the solid precipitation portion reducing during warming, it would still be a large absolute value). In the rest of the Kamchatka systems $\triangle A, C$ will range from 30 to $150 \mathrm{~mm}$ as a result of reduced snow nourishment because of strong warming. The glaciers of the Shiveluch Volcano attain negative $\triangle A, C$ values at the ELA due to rather abrupt decrease of the solid-precipitation fraction.

Judging from the glacier-balance averages both for the baseline and projected periods, the glacier systems have different sensitivities to current climatic conditions and predicted future climate change. Under a constant climate, when glacier mass balance is close to zero, the glacier will not change; but assuming the same constant climate, if mass balance is positive the glacier will expand, while if it is negative it will shrink. The balance trend, stability or change, and its sign are controlled by climatic conditions. A glacier can "keep up" with climate change - in this case its balance also remains near zero as well as consistent with climate. Among the glaciations considered, only that of the Chersky Range has been in this state during the baseline period. Glaciers of the Orulgan, the western slope of Sredinniy Range, the Kluchevskya Volcano group and Tolbachek in Kamchatka were growing at that time. The rest have already retreated. For the 2040-2069 period the northern knot of Orulgan glaciers and glaciers of the Kluchevskya and Tolbachek volcanoes are predicted to come into equilibrium with climate. Despite the intensive warming scenario, the Chersky glaciers will still

\section{Mountain glaciers of} NE Asia

M. D. Ananicheva et al.

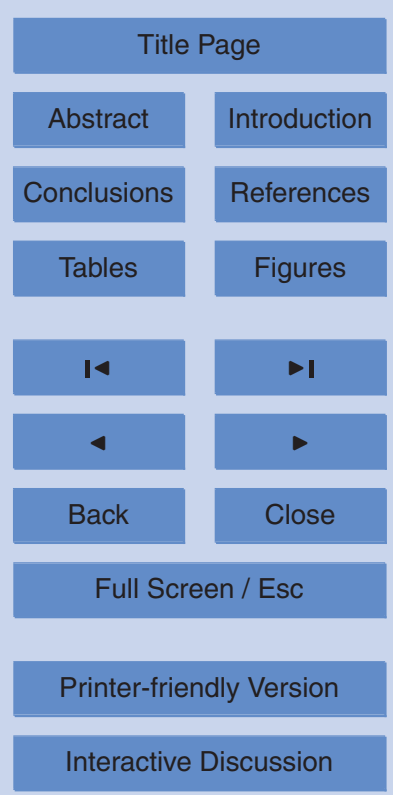


be consistent with climate: this is due to a combination of elevation, relief forms and corresponding glacier morphology and regime, leading to their quite slow movement and change. Glaciers of the Sredinniy and Kronotsky ranges, Shiveluch and southeast Kamchatka volcanoes will undergo accelerated retreat and provide evidence of a time 5 lag when compared with the warming rate.

\section{Conclusions}

A new approach involving calculating the average ELA and glacier-termini level for present and projected future climate states has been used to assess glacier-system change due to predicted climate change. We have used this approach to study glacier systems with a wide spectrum of morphology and regime types from small corrie glaciers of the Orulgan range to large dendritic glaciers of the Chersky Range and specific volcano-glacier complexes of Kamchatka. Glacier nourishment conditions vary widely. The reaction of these glacier systems to climate warming is found to vary considerably. Calculation of projected changes predict that the upward shift of ELA, $\Delta H_{\text {ela }}$, 15 is less in northern parts of NE Siberia (230 m as against $500 \mathrm{~m}$ in the south), while in Kamchatka $\Delta H_{\text {ela }}$ as a rule is greater and depends on precipitation rate. Our calculations also predict the disappearance of some glacier systems, while others will preserve $70 \%$ of their present area.

Our simple, climate-based approach allows the evaluation of the behavior of mountain glacier systems under specified climatic scenarios for any glaciated mountains worldwide and can serve as a tool for glacier morphology and regime forecasts for the medium-term future. The originality of our approach consists in the definition of glacier-climate characteristics for a glacier system, and we have applied this here for the first time to a projection of glacier-system change. By so doing, we have derived important information about the climate sensitivity of glaciers in Northeast Siberia and on the Kamchatka Peninsula.

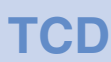

2, 1-21, 2008

\section{Mountain glaciers of} NE Asia

M. D. Ananicheva et al.

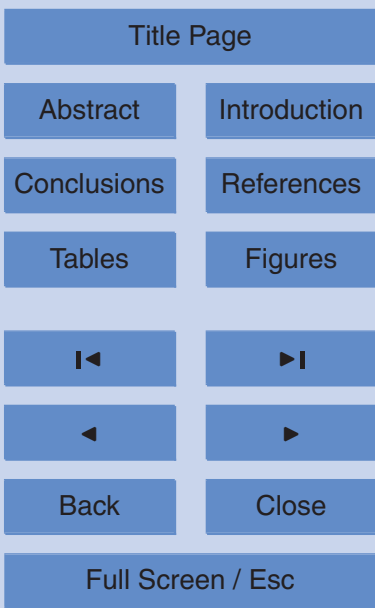

Printer-friendly Version

Interactive Discussion 


\section{References}

Ananicheva, M. D., Davidovich, N. V., and Mercier, J.-L.: Climate change in North-East of Siberia in the last hundred years and recession of Suntar-Khayata glaciers - Data of glaciologic studies - Moscow, Pub. 94, 216-225 , 2003, (in Russian with English summary and figure captions).

Ananicheva, M. D. and Davidovich, N. V.: Reconstruction of the Suntar-Khayata glaciation's in the periods of Quaternary climatic optima, Data of glaciological studies, Publ. 93, 73-79, 2002 (in Russian with English summary and figure captions).

Ananicheva, M. D. and Krenke, A. N.: Evolution of Climatic Snow Line and Equilibrium Line Altitudes- North-Eastern Siberia Mountains in the 20th Century - Ice and Climate News, The WCRP Climate and Cryosphere Newsletter, N 6, July 2005, 1-6, 2005.

Ananicheva, M. D., Kapustin, G. A., and Koreysha, M. M.: Glacier changes in Suntar-Khayata mountains and Chersky Range from the Glacier Inventory of the USSR and satellite images 2001-2003, Data of glaciologic studies, Moscow, 2006, Pub. 101, 163-169, 2006 (in Russian with English summary and figure captions).

Bacher, A., Oberhuber, J. M., and Roeckner, E.: ENSO dynamics and seasonal cycle in the tropical Pacific as simulated by the ECHAM4/OPYC3 coupled general circulation model, Clim. Dynam., 14, 431-450, 1998.

Bogdanova, A. G.: Method of for calculation of solid and mixed precipitation proportion in their monthly standard, Data of Glaciological Studies, publ. 26, 202-207, 1976 (in Russian with English summary and figure captions).

Bogdanova, E. G., Ilyin, B. M., and Dragomilova, I. V.: Application of a comprehensive bias correction model to precipitation measured at Russian North Pole drifting stations, J. Hydrometeorol., 3, 700-713, 2002.

Davidovich, N. V.: Kamchatka glaciation during the Holocene Optimum (2006) Data of glaciologic studies, publ. 101, 221-229, 2006 (in Russian with English summary and figure captions).

Davidovich, N. V. and Ananicheva, M. D.: Prediction of possible changes in glacio-hydrological characteristics under global warming: south-eastern Alaska, USA, J. Glaciol., 42, 407-412, 30 1996.

Dowdeswell, J. A. and Hagen, J. O.: Arctic ice caps and glaciers, in: Mass Balance of the Cryosphere: Observations and Modelling of Contemporary and Future Changes, edited by:

Mountain glaciers of NE Asia

M. D. Ananicheva et al.

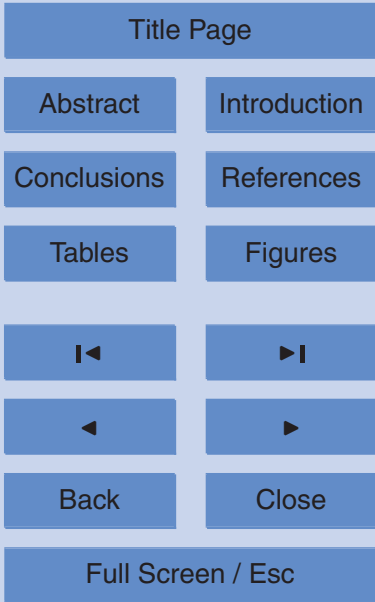

Printer-friendly Version

Interactive Discussion 
Bamber, J. L. and Payne, A. J., Cambridge University Press, pp. 527-557, 2004.

Hanna, E. and Valdes, P.: Validation of ECMWF (re)analysis surface climate data, 1979-98, for

Greenland and implications for mass balance modelling of the Ice Sheet, Int. J. Climat., 21,

171-195, 2001.

5 Hess, H.: Die Gletscher, Brounshweig: Verlag von F. Vieweg u. S., 426 pp., 1904.

IPCC Second Assessment Report: The science of Climate Change 1995, edited by: Houghton, J.T., Meira Filho, L.G., Callander, B.A., Harris, N., Kattenberg, A., and Maskell, K., Cambridge University Press, UK, 572 pp., 1996.

Kalesnik, S. V.: Ocherki glyasiologii (Glaciological essays), Moscow, Ychpedgiz, 182, 1963 (In Russian).

Koreisha, M. M.: Glaciation of Verkhoyansk-Kolyima Region, Moscow, 143 pp., 1991 (in Russian).

Krenke, A. N.: Mass exchange in glacier systems on the USSR territory. Leningrad, Hydrometeoizdat, 288, 1982 (In Russia, extended English summary).

Matsumoto, K. Y., Shiraiwa, T., Yamaguchi, S., Sone, T., Nishimira, K., Muravyev, Y. D., Khomentovsky, P. A., and Yamagata, K.: Meteorological observations by automatic weather stations (AWS) in alpine regions of Kamchatka, Russia, 1996-1997, Cryospheric studies, in Kamchatka II, Hokkaido University: Sapporo, 155-170, 1999.

Muraviev Y. D.: Present-day glaciation in Kamchatka -distribution of glaciers and snow, Cryospheric studies in Kamchatka II, Institute of Low Temperature Science, Hokkaido University, 1-7, 1999.

Shmakin, A. B. and Popova, V. V.: Dynamics of climate extremes in northern Eurasia in the late 20th century, Izvestiya AN, Fizika Atmosfery i Okeana, 42, 157-166, 2006 (In Russian, English summary and figure captions).

Vinogradov, V. N.: Present glacatiotion of the areas of active volcanism, Moscow, "Nauka", 103 pp., 1975 (in Russian, extended English summary).

Vinigradov, V. N. and Martiyanov, V. L.: Heat balance of Kozelskiy Glacier (Avachnskaya Volcano group), Data of glacier studies, Moscow, publ. 37, 182-187, 1980 (In Russian, English summary and figure captions).

Mountain glaciers of NE Asia

M. D. Ananicheva et al.

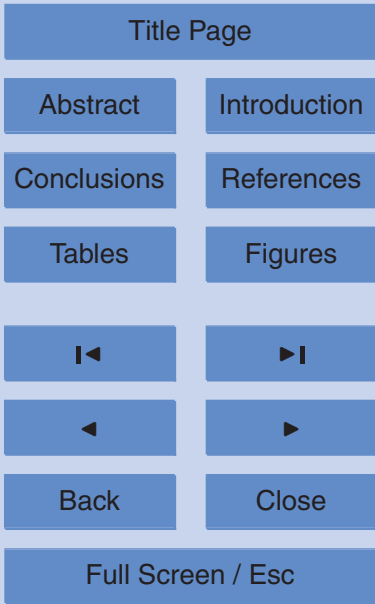

Printer-friendly Version

Interactive Discussion 
Table 1.

Change of the glacier systems characteristics in NE Siberia and Kamchatka up to the mid-21st Century (2040-2069 rr.).

2, 1-21, 2008

\begin{tabular}{|c|c|c|c|c|c|c|c|c|c|}
\hline \multirow[t]{2}{*}{ Glacier system } & \multirow{2}{*}{$\begin{array}{l}\text { The shift of } \Delta H_{\text {ela }} \\
\text { (from basic to pro- } \\
\text { jected period), } \\
\text { m }\end{array}$} & \multicolumn{2}{|c|}{$\begin{array}{l}\text { The elevation diapa- } \\
\text { son of the glacier } \\
\text { system, } m\end{array}$} & \multicolumn{2}{|c|}{$\begin{array}{l}\text { Glaciated area, } \\
\mathrm{km}^{2}, \%\end{array}$} & \multicolumn{2}{|c|}{$\begin{array}{l}\text { Ablation-accumulation } \\
\text { at the } H_{\text {ela }}, \mathrm{mm}\end{array}$} & \multicolumn{2}{|c|}{ Balance, $\mathrm{cm} /$ year } \\
\hline & & $\begin{array}{l}\text { Basic } \\
\text { period }\end{array}$ & $\begin{array}{l}\text { Projected } \\
\text { period }\end{array}$ & $\begin{array}{l}\text { Basic } \\
\text { period, } \\
\mathrm{km}^{2}\end{array}$ & $\begin{array}{l}\text { Projected } \\
\text { period, } \\
\mathrm{km}^{2}(\%)\end{array}$ & $\begin{array}{l}\text { Basic } \\
\text { period }\end{array}$ & $\begin{array}{l}\text { Projected } \\
\text { period }\end{array}$ & $\begin{array}{l}\text { Basic } \\
\text { period }\end{array}$ & $\begin{array}{l}\text { Projected } \\
\text { period }\end{array}$ \\
\hline \multicolumn{10}{|c|}{ NE Siberia } \\
\hline Orulgan Northern Knot & 250 & 750 & 400 & 7 & $2(27)$ & 740 & 1230 & +23 & 0 \\
\hline Orulgan Southern Knot & 500 & 760 & 0 & 12 & 0 & 580 & 0 & +14 & - \\
\hline Chersky - Erikit knot & 320 & 700 & 200 & 7 & $1(10)$ & 710 & 1020 & +7 & 0 \\
\hline Chersky-Buordakh & 300 & 1640 & 1280 & 63 & $18(29)$ & 700 & 1050 & -2 & -11 \\
\hline Chersky-Terentykh & 300 & 1520 & 1180 & 28 & $8(29)$ & 720 & 1130 & +2 & +6 \\
\hline Suntar-Khayata, North & 350 & 1080 & 520 & 111 & $26(23)$ & 620 & 850 & -26 & -70 \\
\hline Suntar-Khayata, South & 500 & 1110 & 60 & 22 & $0,4(2)$ & 460 & 650 & -40 & -30 \\
\hline \multicolumn{10}{|c|}{ Kamchatka } \\
\hline $\begin{array}{l}\text { Sredinny Range } \\
\text { Eastern Slope }\end{array}$ & 600 & 2850 & 2160 & 124 & $24(20)$ & 1430 & 1460 & -44 & -170 \\
\hline $\begin{array}{l}\text { Sredinny Range } \\
\text { Western Slope }\end{array}$ & 570 & 1900 & 1330 & 264 & $55(21)$ & 1430 & 1470 & +20 & -44 \\
\hline Shiveluch Volcano & 600 & 3240 & 2720 & 30 & $16(52)$ & 1160 & 1080 & -36 & -50 \\
\hline Kluchevskaya Group & 420 & 3950 & 3660 & 124 & $85(69)$ & 1000 & 1100 & +31 & -4 \\
\hline Tolbachek Volcano & 580 & 3085 & 2680 & 70 & $33(47)$ & 1200 & 1350 & +50 & +3 \\
\hline Tumrok and Gemchen ranges & 430 & 1020 & 0 & 11 & 0 & 1710 & 0 & -81 & - \\
\hline Khronotsky Range & 510 & 1150 & 260 & 91 & $9(10)$ & 3350 & 3800 & -48 & -116 \\
\hline Valaginsky Range & 610 & 1000 & 0 & 9 & 0 & 1400 & 0 & -40 & - \\
\hline $\begin{array}{l}\text { Volcanows of South-Eastern } \\
\text { Kamchatka }\end{array}$ & 300 & 2660 & 2340 & 34 & $14(41)$ & 1350 & 1550 & -44 & -60 \\
\hline Ichinsky Volcano & 740 & 2080 & 780 & 29 & $6(22)$ & 1510 & 1550 & +17 & +3 \\
\hline $\begin{array}{l}\text { Ichinsky Volcano (with ac- } \\
\text { count of blow-out from the } \\
\text { slopes) }\end{array}$ & $1210^{*}$ & 2080 & 0 & 29 & 0 & 1510 & $800^{*}$ & +17 & - \\
\hline
\end{tabular}

Mountain glaciers of NE Asia

M. D. Ananicheva et al.

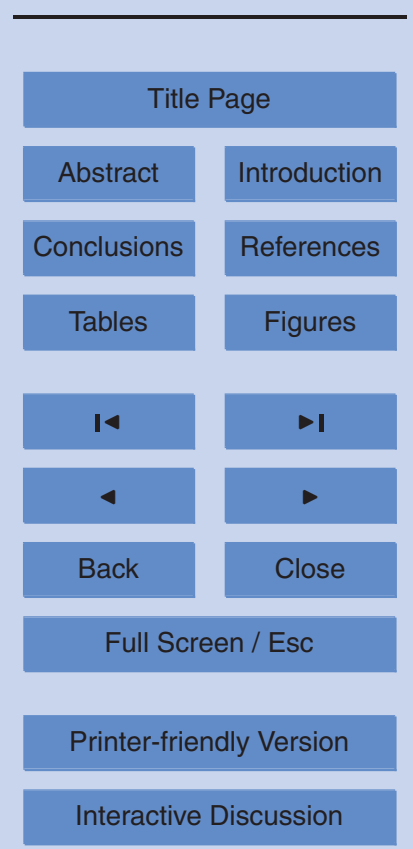
will not exist under the scenario used. 


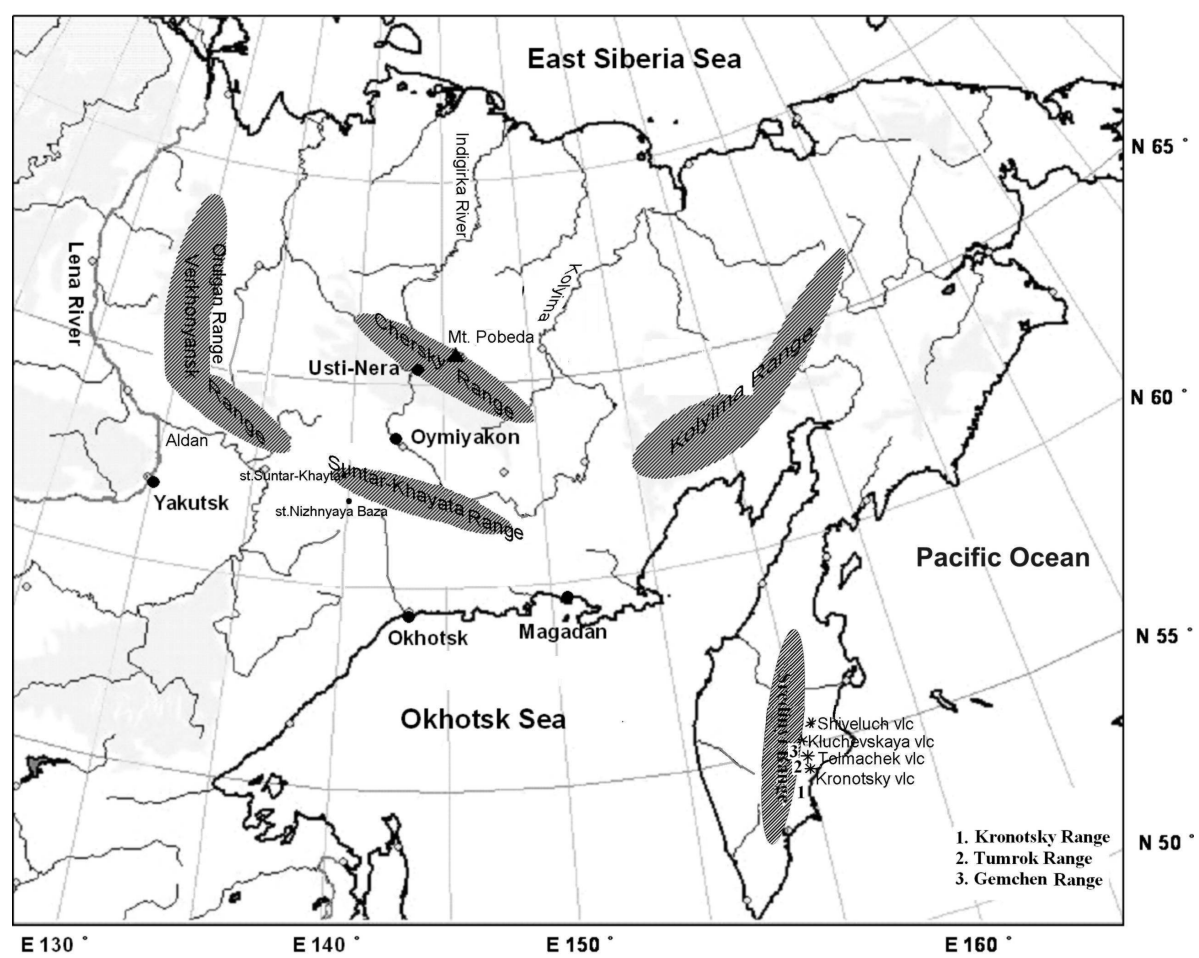

\section{Mountain glaciers of NE Asia}

M. D. Ananicheva et al.

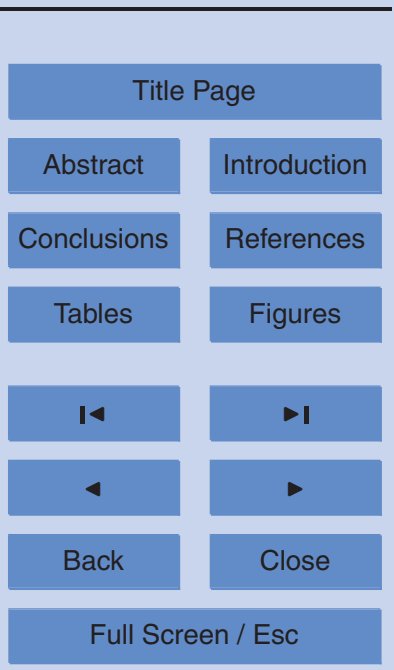

Printer-friendly Version

Fig. 1. Location map of study region. 


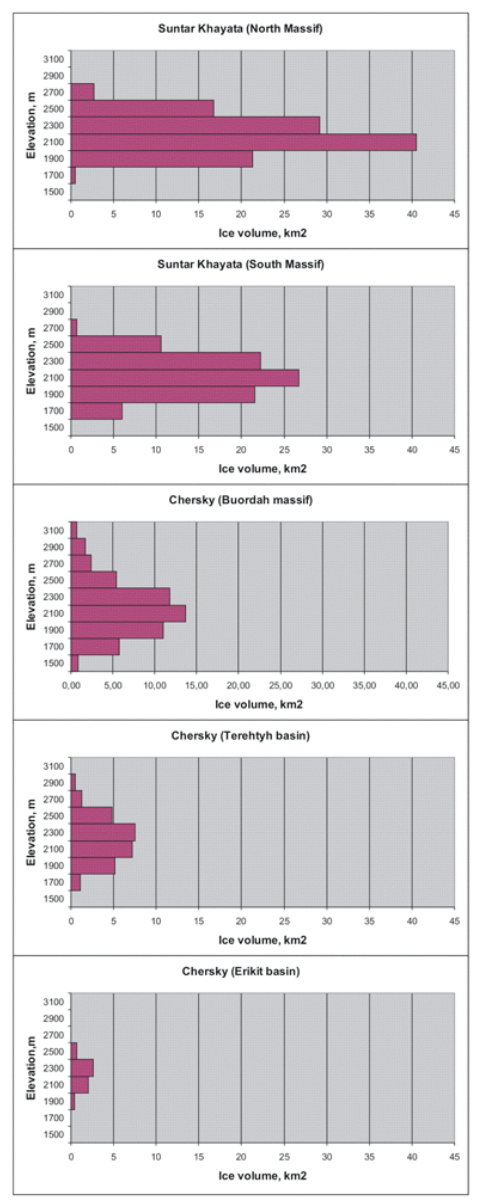

2, 1-21, 2008

Mountain glaciers of NE Asia

M. D. Ananicheva et al.

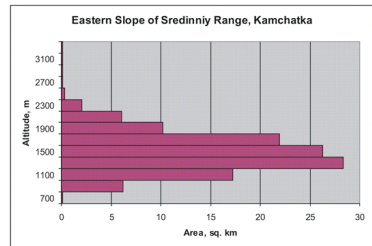

Title Page

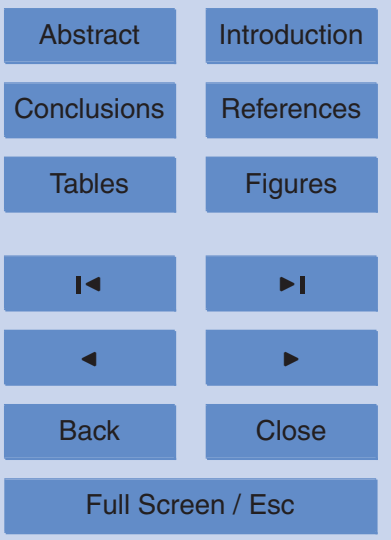

Printer-friendly Version

Interactive Discussion

Fig. 2. Examples of hypsographic curves (distribution of ice area via altitude) for NE Siberia glacier systems. 

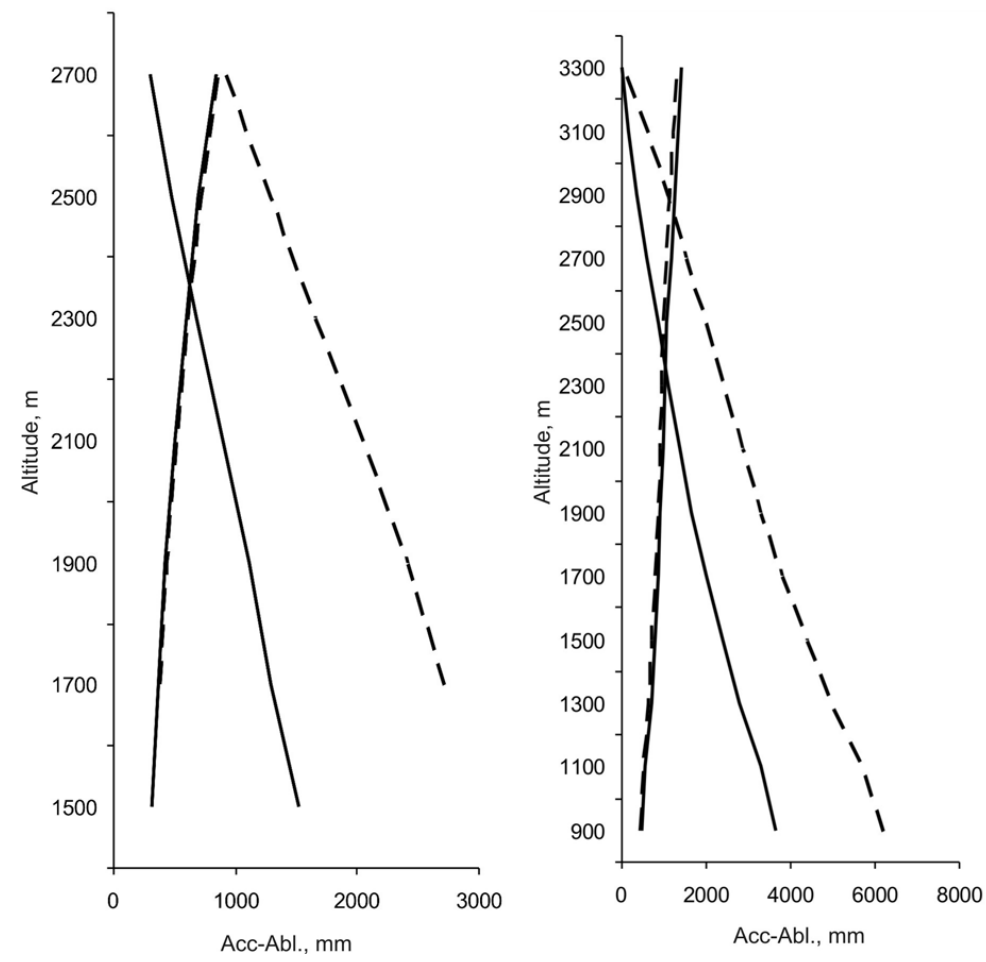

2, 1-21, 2008

Mountain glaciers of NE Asia

M. D. Ananicheva et al.

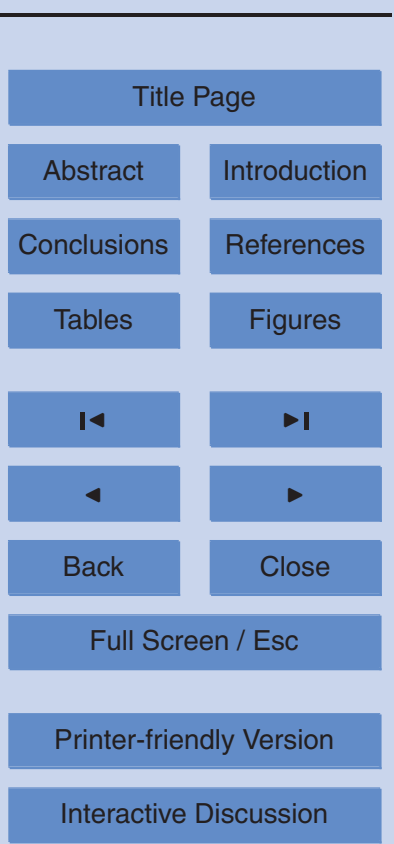

Fig. 3. Vertical profiles of ablation and accumulation for baseline/present (solid lines) and projected by ECHAM scenario for 2040-2069 (broken lines) for two different glacier systems: (a) Northern massif of Suntar-Khayata (NE Siberia); and (b) Kluchevskaya volcano group of glaciers (Kamchatka). The method of construction of these profiles is explained in detail in the main text. 


\section{Northern Massif of Suntar-Khayata, Glacier 31}

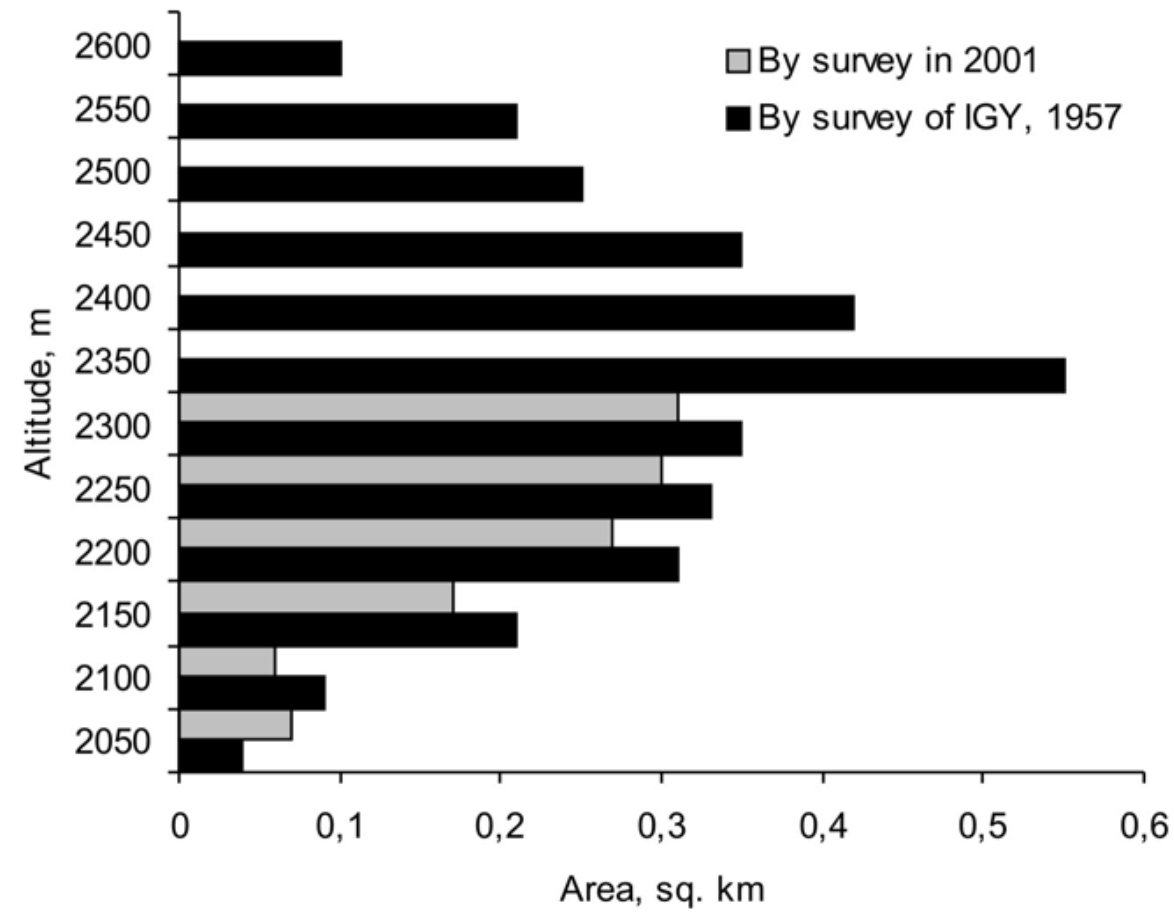

Fig. 4. Distribution of ice area via altitude of Glacier 31 (Suntar-Khayata Range) derived from 1957 and 2001 surveys.
2, 1-21, 2008

Mountain glaciers of NE Asia

M. D. Ananicheva et al.

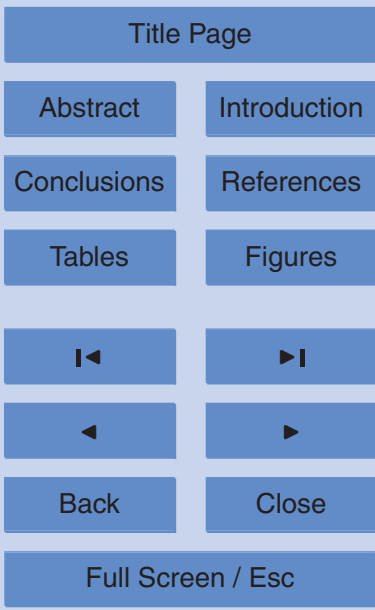

Printer-friendly Version

Interactive Discussion 